\title{
Induksi Kalus Gaharu dengan NAA dan BAP Secara In Vitro
}

\section{Callus Induction of Agarwood Using NAA and BAP In Vitro}

\author{
Amalina Wahyuni*, Benni Satria, Aprizal Zainal \\ Departement of Agrotechnology, Faculty of Agriculture, Universitas Andalas, Padang, Indonesia \\ *Corresponding author: wahyuniamalina@gmail.com
}

Received: November 27, 2019; Accepted: March 30, 2020; Published: April 1, 2020

\begin{abstract}
Agarwood has a high economic value because they have many benefits that cause agarwood to be hunted to meet the increasing market demand and its presence in nature is decreasing due to unwise conventional retrieval systems. The research objectives were to study the effect and determine the best concentration of NAA and BAP in callus induction of agarwood (Aquilaria malaccensis Lamk.). This research was conducted in the Tissue Culture Laboratory, Faculty of Agriculture, Andalas University from October 2018 until January 2019. The leaves of Agarwood were used as explants. The method used was completely randomized design (CRD) with different combinations of NAA and BAP $(1.5+0.5 \mathrm{ppm}, 3.0+0.5 \mathrm{ppm}, 1.5+1.0 \mathrm{ppm}$, and $3.0+1.0 \mathrm{ppm})$. Data were analyzed using the $F$ test and continued with Duncan's Multiple Range Test at a level of $5 \%$. The results showed that there was the effects of combination of growth regulator substances NAA and BAP on callus induction of agarwood. The concentration of NAA $3.0 \mathrm{ppm}+$ BAP $0.5 \mathrm{ppm}$ was the best in inducing callus with the percentage of explants life and explants form callus with $100 \%$. The color of callus obtained varies, yellow, brownish yellow and brown. All structures callus gained in this research was compact. Yellow callus and compact structure could be utilized for organogenesis.
\end{abstract}

Key words: explants, growth regulator, tissue culture

Cite this as: Wahyuni, A., Satria, B., \& Zainal, A. (2020). Induksi Kalus Gaharu dengan NAA dan BAP Secara In Vitro. Agrosains : Jurnal Penelitian Agronomi 22(1): 39-44. DOI: http://dx.doi.org/10.20961/agsjpa.v22i1.36007

\section{PENDAHULUAN}

Indonesia merupakan salah satu negara yang mempunyai tingkat keanekaragaman jenis pohon yang tinggi. Besarnya peran serta manfaat pohon dalam kehidupan sehari-hari, mengakibatkan banyaknya terjadi kegiatan eksploitasi seperti penebangan pohon secara liar yang mana hal ini berdampak pada kualitas lingkungan. Salah satu tanaman hutan yang dieksploitasi adalah tanaman kayu gaharu. Gaharu memiliki nilai ekonomi yang tinggi karena digunakan sebagai bahan baku minyak wangi, kosmetik, obat-obatan, dupa dan sebagai pencegah stres. Kegunaan gaharu yang cukup banyak ini sudah seharusnya menjadikan Indonesia lebih giat dalam budidaya gaharu sehingga dapat menambah devisa negara serta pelestarian plasma nutfah gaharu (Sumarna, 2003).

Selama ini gaharu dieksploitasi secara berlebih dan tidak bijaksana sehingga populasinya semakin menurun. Permintaan yang tinggi tidak diimbangi dengan produksi tanaman yang tinggi pula, sehingga menyebabkan tanaman ini hampir punah. Akibat penurunan tersebut, sejak tahun 2001, tanaman penghasil gaharu termasuk dalam CITES (Convention on International Trade in Endengered Species of Wild Fauna and Flora) dimana di dalamnya termasuk kategori APENDIK II atau langka
(Millang et al., 2011). Setelah masuk ke dalam kategori tersebut, kegiatan ekspor gaharu diatur oleh pemerintah dengan menurunkan kuotanya. Pada tahun 2000, sebelum dikategorikan APENDIK II CITES kuota ekspor mencapai $200.000 \mathrm{~kg}$, sedangkan setelah masuk kategori APENDIK II CITES kuota diturunkan menjadi 125.000 (Semiadi et al., 2010).

Perlu adanya peningkatan budidaya tanaman gaharu untuk mengatasi kelangkaan terutama dalam proses penyediaan bibit tanaman gaharu. Akan tetapi, menurut Zubaidi dan Farida (2008), penyediaan bibit menjadi kendala dalam budidaya tanaman gaharu. Budidaya tanaman gaharu dapat dilakukan secara generatif yaitu dengan menggunakan biji. Kendala yang dihadapi ketika dilakukan perbanyakan dengan menggunakan biji adalah pada perkecambahan yang daya kecambahnya relatif rendah, yaitu $47 \%$. (Gustian dan Satria, 2009). Menurut Saikia et al. (2013), perbanyakan melalui biji memiliki tingkat kematian yang cukup tinggi dan rata-rata kelangsungan hidupnya rendah.

Budidaya secara vegetatif yaitu dengan stek dan cangkok memiliki metode yang kurang berhasil. Hal ini karena kemampuan berakar yang cepat hilang dengan semakin bertambahnya usia tanaman dan keterbatasan bahan tanam yang dapat diperoleh di 
waktu tertentu. Metode ini juga menghasilkan bibit dengan skala terbatas, padahal kebutuhan komersil cukup tinggi (Sharma dan Vashistha, 2015).

Salah satu teknik budidaya yang dapat menjadi alternatif adalah dengan teknik kultur jaringan. Teknik kultur jaringan merupakan suatu metode penanaman protoplas, sel, jaringan dan organ pada media buatan dalam kondisi aseptik sehingga dapat beregenerasi menjadi tanaman lengkap yang sifatnya sama seperti induknya. Teknik kultur jaringan ini diharapkan dapat memberikan alternatif dalam upaya konservasi dan perkembangan gaharu dimasa yang akan datang (Zulkarnain, 2009).

Keberhasilan kultur jaringan melalui penggandaan tunas, organogenesis maupun embriogenesis somatik tergantung dari beberapa faktor, meliputi faktor eksternal dan faktor internal. Salah satu faktor eksternal yang mempengaruhi proses pertumbuhan eksplan adalah zat pengatur tumbuh. Saat ini, sudah mulai dikembangkan pembudidayaan tanaman gaharu menggunakan kultur jaringan dengan berbagai macam variasi ZPT pada media kultur. Penambahan zat pengatur tumbuh dari golongan auksin NAA dan sitokinin BAP pada komposisi media yang digunakan dan jenis tanaman yang akan diperbanyak dapat meningkatkan multiplikasi tanaman pada kultur jaringan (Puteri et al., 2014). Pada penelitian Saikia (2012), menyatakan bahwa gaharu jenis Aquilaria filaria yang dikulturkan pada media MS dilengkapi dengan BAP $(0,5 \mathrm{mg} / \mathrm{l})+\mathrm{NAA}(1,0 \mathrm{mg} / \mathrm{l})$ pada konsentrasi sukrosa 4\% merupakan yang terbaik untuk mendapatkan biomassa kalus maksimum yaitu 7,368 \% dibandingkan media MS dilengkapi dengan 2, 4-D (2 mg/l) + Kinetin (0.1 mg/l) dan 2, 4-D (2 mg/l) + BAP $(0.5 \mathrm{mg} / \mathrm{l})$. Namun, pengkajian pemberian NAA dan BAP untuk efektifitas pembentukan kalus dengan konsentrasi yang tepat khususnya untuk tanaman gaharu masih belum memadai. Tujuan penelitian ini yaitu untuk mengetahui pengaruh dan mendapatkan konsentrasi NAA dan BAP terbaik dalam induksi kalus gaharu.

\section{BAHAN DAN METODE}

Penelitian ini telah dilaksanakan di Laboratorium Kultur Jaringan, Fakultas Pertanian, Universitas Andalas, Padang pada bulan Oktober 2018 hingga Januari 2019.

Alat yang digunakan dalam penelitian ini yaitu Laminar Air Flow (LAF), autoklaf, timbangan analitik, pinset, gunting, oven, magnetic stirrer, hot plate, pisau scapel, erlen meyer $1000 \mathrm{~mL}$, gelas piala 50 $\mathrm{mL}$, botol kultur, bunsen, petri dish, gelas ukur $10 \mathrm{~mL}$, botol kaca, rak kultur, hand sprayer, $\mathrm{pH}$ meter, mikropipet, kertas $\mathrm{pH}$, alat tulis, dan kamera Panasonic Lumix.

Bahan yang digunakan yaitu daun gaharu (Aquilaria malaccensis) pada bagian pucuk tanaman sebagai eksplan, aquades steril, alkohol $70 \%$ dan $96 \%$, larutan tween 20, NAA, BAP, fungisida, bakterisida, media $\mathrm{MS}$, agar, mioinositol, $\mathrm{HCl}, \mathrm{NaOH}$, sukrosa, plastik, karet gelang, lakban bening, kertas label, plastik wrap, tisu, aluminium foil, spritus dan $\mathrm{NaClO}$.

Rancangan yang digunakan dalam penelitian ini yaitu rancangan acak lengkap ( $R A L$ ) yang terdiri dari 4 taraf perlakuan, yaitu: A (NAA 1,5 ppm + BAP 0,5 ppm); B (NAA 3,0 ppm + BAP 0,5 ppm); C (NAA 1,5 ppm + BAP 1,0 ppm); D (NAA 3,0 ppm + BAP 1,0 ppm). Setiap perlakuan diulang sebanyak 5 kali, sehingga terdapat 20 satuan percobaan dan setiap satuan percobaan terdiri 2 botol kultur. Pada masing-masing botol kultur, ditanam satu eksplan dan diamati semua populasinya. Apabila terdapat perbedaan nyata pada uji F, analisis dilanjutkan dengan uji Duncan Multiple Range Test (DMRT) dengan taraf 5\% (Duncan, 1955).

\section{HASIL DAN PEMBAHASAN \\ Waktu Munculnya Kalus}

Pengamatan waktu munculnya kalus diamati setiap hari yang dimulai dari hari pertama tanam hingga eksplan membentuk jaringan baru yang belum terdiferensiasi atau yang biasa disebut dengan kalus. Waktu munculnya kalus dihitung dengan hari setelah tanam (HST). Pembentukan kalus dapat terjadi karena eksplan yang memiliki jaringan meristematik dan berinteraksi langsung antara jaringan tanaman dengan pengaturan zat pengatur tumbuh yang terdapat dalam media (Lizawati, 2012).

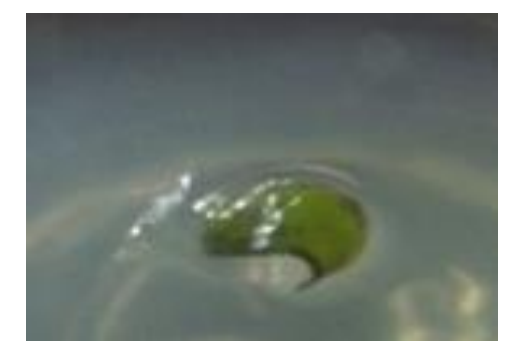

Gambar 1. Kondisi Eksplan Umur 3 Hari Setelah Tanam Sumber: Pribadi

Berdasarkan hasil pengamatan, proses pembentukan kalus diawali dengan pembengkakan pada eksplan. Pembengkakan ini ditandai dengan adanya pembesaran dan permukaan eksplan membentuk tonjolan yang mulai terjadi ketika eksplan berumur 3-5 hari setelah tanam (Gambar 1).

Pembengkakan ini kemudian disusul dengan terbentuknya kalus pada pinggir daun dan permukaan pertulangan daun. Pembengkakan yang terjadi pada eksplan ini menandakan bahwa eksplan sudah merespon media yang diberikan, dimana media tersebut diserap oleh eksplan sebagai nutrisi untuk pertumbuhan kalus. Sesuai dengan penelitian Priyono et al. (2000), eksplan dapat membentuk kalus pada beberapa minggu setelah penaburan. Terbentuknya kalus disebabkan adanya rangsangan luka yang menyebabkan keseimbangan pada dinding sel berubah arah, sebagian protoplas mengalir ke luar sehingga mulai terbentuk kalus.

Hasil analisis data menunjukkan bahwa pemberian kombinasi zat pengatur tumbuh NAA dan BAP memberikan pengaruh yang nyata terhadap 
waktu munculnya kalus (Tabel 1). Pada Tabel 1 tersebut, diketahui bahwa perlakuan dengan pemberian NAA 1,5 ppm + BAP 0,5 ppm memiliki waktu untuk berkalus paling lama yaitu 29,90 hari. Hal ini berarti bahwa pada kombinasi konsentrasi NAA dan BAP tersebut belum mampu menginduksi kalus dengan optimal. Menurut Hayati et al. (2010), induksi kalus dipengaruhi oleh rasio auksin dan sitokinin yang seimbang sehingga diperlukan kombinasi yang tepat agar dapat menginduksi pembentukan kalus yang optimal. Selanjutnya, perlakuan dengan pemberian NAA 3,0 ppm + BAP 1,0 ppm merupakan perlakuan dengan rata-rata waktu munculnya kalus paling cepat yaitu 22,60 hari dimana waktu mulai berkalus eksplan dimulai pada hari ke-21 setelah tanam.

Tabel 1. Rata-rata waktu munculnya kalus pada eksplan daun gaharu dengan pemberian NAA dan BAP

\begin{tabular}{cc}
$\begin{array}{c}\text { Konsentrasi } \\
\text { NAA + BAP }(p p m)\end{array}$ & $\begin{array}{c}\text { Waktu munculnya } \\
\text { kalus (HST) }\end{array}$ \\
\hline $1,5+0,5$ & $29,90 \mathrm{a}$ \\
$3,0+0,5$ & $24,50 \mathrm{bc}$ \\
$1,5+1,0$ & $26,00 \mathrm{~b}$ \\
$3,0+1,0$ & $22,60 \mathrm{c}$ \\
\hline
\end{tabular}

Keterangan: Angka yang diikuti huruf yang sama menunjukkan tidak berbeda nyata pada Uji Jarak Berganda Duncan taraf $5 \%$

Berdasarkan Tabel 1, dapat diketahui bahwa perlakuan NAA 3,0 ppm + 0,5 ppm BAP merupakan kombinasi terbaik dalam waktu pembentukan kalus. Karena dengan konsentrasi NAA yang sama yaitu 3,0 ppm dikombinasikan dengan konsentrasi BAP yang lebih sedikit yaitu $0,5 \mathrm{ppm}$, mampu membentuk kalus dalam waktu yang lebih cepat dibandingkan dengan konsentrasi NAA dan BAP yang lainnya. Selain itu, dapat diketahui juga bahwa peningkatan konsentrasi NAA dan konsentrasi BAP yang tetap mampu mempercepat waktu munculnya kalus pada tanaman gaharu. Hal ini menandakan bahwa konsentrasi auksin yang tinggi sangat berpengaruh terhadap waktu munculnya kalus.

Isnaini dan Situmorang (2005) menyatakan, konsentrasi auksin lebih tinggi dari sitokinin mendorong eksplan membentuk kalus dan akar (rootlet), tetapi apabila konsentrasi sitokinin lebih tinggi dari auksin maka akan mendorong eksplan membentuk tunas atau shootlet. Pembentukan kalus juga dipengaruhi oleh interaksi hormon endogen yang terkandung dalam eksplan dengan penambahan zat pengatur tumbuh eksogen yang ditambahkan pada media. Pemberian NAA 3,0 ppm + BAP 0,5 ppm diduga mampu mengimbangi auksin dan sitokinin endogen yang ada dalam jaringan tanaman sehingga mempengaruhi waktu pembentukan kalus. Adanya zat pengatur tumbuh endogen dalam jaringan mengakibatkan proses proliferasi sel mengarah pada pembentukan kalus. Hal ini sesuai dengan pernyataan Warneing dan Philips (1981) bahwa hormon endogen saja yang terdapat dalam jaringan eksplan akan mempengaruhi proses fisiologis dan morfologis tanaman. Pada penelitian Ramanta (2018), eksplan tanaman gaharu tercepat membentuk kalus pada hari ke-17,4 dengan penambahan 2,4-D pada media. Perbedaan waktu munculnya kalus ini, diduga karena perbedaan zat pengatur tumbuh yang diberikan dalam media. Menurut Yulianti (2015), penggunaan zat pengatur tumbuh yang berbeda-beda akan memberikan respon yang berbeda pula pada setiap individu eksplan. Arianto et al. (2013) menyatakan bahwa zat pengatur tumbuh pada media tanam akan berdifusi ke dalam jaringan tanaman melalui pangkal eksplan yang terluka akibat irisan, kemudian zat pengatur tumbuh yang telah diserap akan menstimulasi terjadinya pembelahan sel, terutama sel-sel yang berada pada pangkal sekitar perlukaan eksplan.

\section{Persentase Eksplan Membentuk Kalus}

Parameter pengamatan ini menunjukkan kemampuan eksplan dalam membentuk kalus dengan mengamati eksplan dari hari setelah penanaman hingga semua eksplan membentuk kalus. Data hasil sidik ragam menggunakan uji $F$ dapat dilihat pada Tabel 2.

Tabel 2. Persentase eksplan gaharu membentuk kalus dengan pemberian NAA dan BAP

\begin{tabular}{cc}
\hline $\begin{array}{c}\text { Konsentrasi } \\
\text { NAA + BAP }(\mathrm{ppm})\end{array}$ & $\begin{array}{c}\text { Persentase eksplan } \\
\text { membentuk kalus }(\%)\end{array}$ \\
\hline $1,5+0,5$ & $70 \mathrm{bc}$ \\
$3,0+0,5$ & $100 \mathrm{a}$ \\
$1,5+1,0$ & $50 \mathrm{c}$ \\
$3,0+1,0$ & $90 \mathrm{ab}$ \\
\hline
\end{tabular}

Keterangan: Angka yang diikuti huruf yang sama menunjukkan tidak berbeda nyata pada Uji Jarak Berganda Duncan taraf $5 \%$

Data pengamatan eksplan berkalus menunjukkan bahwa pemberian kombinasi zat pengatur tumbuh NAA dan BAP mempunyai respon yang berbeda-beda terhadap persentase eksplan membentuk kalus. Berdasarkan Tabel 2 diketahui bahwa adanya pengaruh yang nyata dari pemberian kombinasi zat pengatur tumbuh NAA dan BAP terhadap persentase eksplan membentuk kalus. Perlakuan dengan pemberian NAA 3,0 ppm + BAP $0,5 \mathrm{ppm}$ mampu membentuk kalus sebesar $100 \%$ yang merupakan persentase paling tinggi dalam pembentukan kalus. Tingginya persentase pembentukan kalus ini menandakan keberhasilan pembentukan kalus. Berdasarkan data di atas, dapat diketahui juga bahwa semakin tinggi konsentrasi zat pengatur tumbuh NAA, semakin tinggi kemampuan eksplan berkalus. Penambahan NAA ke dalam media mampu mempengaruhi pembentukan kalus seperti yang diungkapkan oleh Hartman et al. (1990) bahwa auksin pada tingkat moderat sampai tinggi merupakan hormon primer dalam produksi kalus.

Persentase eksplan membentuk kalus yang tinggi memperlihatkan bahwa adanya respon yang kuat dari eksplan dalam menyerap unsur hara yang ada pada media sehingga merangsang perkembangan jaringan untuk membentuk kalus. Persentase kalus yang tinggi juga disebabkan karena eksplan yang digunakan adalah jaringan muda yang memiliki sifat 
meristematik yang memiliki hormon endogen yang aktif membelah dan kemudian dikombinasikan dengan hormon eksogen dari kelompok auksin (NAA) dan sitokinin (BAP) sehingga sel-sel melakukan proliferasi membentuk kalus (Satria et al., 1999). Berdasarkan data yang didapatkan, diketahui bahwa pemberian NAA 3,0 ppm + BAP 0,5 ppm merupakan kombinasi terbaik dan dapat dikatakan lebih responsif dalam pembentukan kalus.

Penelitian Karlianda et al. (2012), eksplan yang mampu membentuk kalus pada konsentrasi NAA 0,2 mg/l yang dikombinasikan dengan BAP 2,0 mg/l didapatkan hanya 37,5 \%. Persentase eksplan pada penelitian ini lebih tinggi, hal ini dapat terjadi karena pengaruh perbedaan konsentrasi zat pengatur tumbuh yang diberikan berbeda, dimana konsentrasi NAA yang diberikan lebih rendah dibandingkan dengan konsentrasi BAP sehingga kemampuan eksplan membentuk kalus tidak optimal. Hal ini dinyatakan oleh Thomy (2012), bahwa secara umum penambahan auksin pada konsentrasi tinggi mampu memacu pembentukan kalus, sebaliknya jika perbandingan auksin dan sitokinin di dalam media lebih rendah akan memacu pertumbuhan eksplan beregenerasi membentuk organ. Selain itu, pembentukan kalus juga dipengaruhi oleh jenis eksplan, kondisi ruang inkubasi serta media tumbuh. Palei (2017) menyatakan, bahwa pembentukan kalus juga bergantung pada jenis eksplan yang digunakan, komposisi media kultur, dan kandungan hormon auksin endogen.

\section{Warna Kalus}

Warna kalus merupakan salah satu parameter pengamatan yang digunakan dalam kultur in-vitro. Warna pada kalus dapat menggambarkan kondisi atau penampilan visual kalus sehingga diketahui sel-sel pada kalus masih aktif membelah atau tidak. Perbedaan warna kalus menunjukkan bahwa tingkat perkembangan kalus berbeda-beda. Pada pengamatan warna kalus, umumnya kalus berwarna hijau pada awal berkalus, kemudian seiring perkembangan kalus mulai berubah warna menjadi kuning, kuning kecoklatan hingga coklat (Tabel 3). Perubahan warna yang awalnya hijau menjadi kuning disebabkan oleh adanya proses degradasi klorofil. Menurut Fatmawati (2008), warna kalus menandakan keberadaan klorofil dalam jaringan, sehingga semakin hijau warna kalus semakin banyak pula kandungan klorofil. Hal ini juga terjadi pada penelitian Lestari dan Purnamaningsih (2001) tentang mikropropogasi daun dewa, bahwa terjadi perubahan warna dari hijau menjadi warna kecoklatan atau putih kekuningan. Respon pemberian kombinasi zat pengatur tumbuh NAA dan BAP terhadap warna kalus ditunjukkan pada Tabel 3.

Berdasarkan Tabel 3 diketahui bahwa peningkatan konsentrasi NAA yang diberikan mampu mempengaruhi warna kalus. Hal ini berarti bahwa dengan meningkatnya konsentrasi auksin yang diberikan dalam media warna kalus semakin menguning. Rahayu et al. (2003) menyatakan bahwa kadar auksin yang tinggi ini berkaitan dengan berkurangnya pigmen klorofil pada kalus. Kenaikan kadar auksin akan menurunkan kandungan klorofil. Penurunan kandungan klorofil ini diduga terjadi karena pengaruh auksin pada metabolisme karbohidrat. Apabila metabolisme karbohidrat terganggu maka sintesis klorofil juga akan terganggu.

Tabel 3. Data pengamatan warna kalus gaharu dengan menggunakan Munsell Color Chart

\begin{tabular}{lll}
\hline $\begin{array}{c}\text { Perlakuan } \\
(\mathrm{ppm})\end{array}$ & Color Chart & Kalus \\
\hline NAA $1,5+$ \\
BAP 0,5
\end{tabular}

Kalus yang dihasilkan berwarna putih kekuningan dan dalam pertumbuhannya kalus tersebut mengalami perubahan warna menjadi kuning, hal ini sesuai dengan pernyataan Mahadi et al. (2014) warna kalus dapat memperlihatkan baik tidaknya pertumbuhan kalus, pigmen putih, dan kuning pada kalus menunjukkan bahwa pertumbuhan kalus tersebut baik. Tsuro (1998) menambahkan bahwa kalus yang berwarna putih kekuningan merupakan jaringan yang belum mengandung kloroplas, tetapi memiliki kandungan butir pati yang tinggi, selain itu kalus berwarna putih kekuningan menandakan bahwa kalus memiliki pertumbuhan dan dalam keadaan yang baik. Menurut Prabakti et al. (2017), warna kalus yang didominasi oleh warna putih, kuning muda menandakan adanya indikasi sifat-sifat embriogenik yang mengarah kepada perkembangan embrio somatik.

Warna kecoklatan pada kalus akibat adanya metabolisme senyawa fenol yang berlebihan dan bersifat toksik karena dapat menghambat pertumbuhan serta mengakibatkan kematian pada jaringan. Tabiyah et al. (2006) menyatakan bahwa perubahan warna menjadi coklat (pencoklatan) dalam kultur jaringan disebabkan karena meningkatnya produksi senyawa fenolat yang diikuti oksidasi oleh aktivitas enzim oksidase dan polimerasinya. Peristiwa pencoklatan ini merupakan peristiwa alamiah dan proses perubahan adaptif bagian tanaman akibat adanya pengaruh fisik seperti pemotongan pada saat penanaman. Faktor lain yang diduga menyebabkan hal ini terjadi yaitu semakin 
bertambahnya umur kalus dan semakin sedikitnya nutrisi akan hara pada media, sehingga sel-sel pada eksplan tidak mendapat sumber energi untuk dapat tumbuh. Sehingga diperlukannya subkultur untuk proliferasi kalus lebih lanjut. Subkultur sebaiknya dilakukan setiap 28 hari sekali. Namun waktu yang tepat untuk memindahkan kultur tergantung dari kecepatan pertumbuhan kalus (Doods dan Robert, 1985).

Dalam kaitannya dengan pembentukan kalus embriogenik, kalus yang embriogenik dicirikan dengan warna kalus yang putih kekuningan dan mengkilat (Lizawati, 2012). Namun dalam penelitian ini warna yang menjadi penciri kalus embriogenik tersebut belum didapatkan. Akan tetapi, bertolak belakang dengan penelitian Claudia (2016) yang mendapatkan embrio tahap globular muncul pada kultur delapan minggu dari kalus berwarna coklat pada tanaman kakao. Sedangkan pada kalus berwarna putih, kuning muda, tidak menghasilkan embrio sama sekali. Perbedaan ini bisa dikarenakan pembentukan kalus embriogenik juga dipengaruhi oleh genotipe tanaman, konsentrasi gula serta keseimbangan zat pengatur tumbuh endogen dan eksogen.

\section{Struktur Kalus}

Struktur kalus merupakan salah satu indikator pertumbuhan kalus. Struktur kalus secara visual dibedakan menjadi dua, yaitu kalus berstruktur friable (remah) dan kalus berstruktur non-friable (kompak). Struktur kalus remah memiliki ruang antar sel yang besar dan ikatan antar sel yang renggang, sehingga kalus mudah pecah bila dipisahkan. Sedangkan sturuktur kalus kompak memiliki ikatan antar sel yang padat dan tidak mudah dipisahkan. Hasil pengamatan tekstur kalus dapat dilihat pada Tabel 4.

Tabel 4. Struktur kalus tanaman gaharu dalam berbagai kombinasi NAA dan BAP

\begin{tabular}{cc}
\hline Konsentrasi & Struktur kalus \\
NAA + BAP $($ ppm $)$ & Kompak \\
$1,5+0,5$ & Kompak \\
$3,0+0,5$ & Kompak \\
$1,5+1,0$ & Kompak \\
$3,0+1,0$ &
\end{tabular}

Struktur kalus yang diperoleh dalam penelitian ini semuanya memiliki susunan sel yang kompak, rapat, padat dan sulit untuk dipisahkan. Dari semua perlakuan pemberian NAA dan BAP, tidak satupun didapatkan kalus yang berstruktur remah. Kalus berstruktur remah menandakan secara umum merupakan kalus yang bersifat embriogenik. Hal yang sama terjadi pada penelitian Ramanta (2018) bahwa kalus yang didapatkan dari semua perlakuan pemberian 2,4-D dan BAP hanya kalus yang berstruktur kompak dari eksplan daun gaharu. Terbentuknya kalus yang berstruktur kompak diduga dipacu oleh adanya hormon auksin endogen yang diproduksi oleh eksplan yang telah tumbuh membentuk kalus tersebut. Kalus kompak dapat disebabkan oleh beberapa hal diantaranya disebabkan karena sel-sel yang semula membelah mengalami penurunan aktivitas proliferasinya. Aktivitas ini dipengaruhi oleh auksin alami yang terdapat pada eksplan asal (Santoso dan Nursandi, 2004). Hal ini juga dikemukakan oleh Ariati (2012), bahwa tekstur kalus yang kompak merupakan efek dari auksin dan sitokinin yang mempengaruhi potensial air dalam sel yang mampu menyebabkan penyerapan air dari media ke dalam sel meningkat sehingga sel menjadi lebih kaku.

Berdasarkan hasil pengamatan tersebut, struktur kalus yang kompak bisa dimanfaatkan untuk organogenesis. Hal ini diungkapkan Wahyuni et al. (2017), kalus yang berstruktur remah cocok dimanfaatkan untuk embriogenesis, sedangkan kalus yang berstruktur kompak lebih cocok digunakan untuk organogenesis, sehingga kalus berstruktur kompak sering disebut sebagai kalus organogenik. Hal ini disebabkan karena kalus kompak akan membentuk secara langsung organ seperti shootlet maupun rootlet tanpa melewati proses embriogenesis. Thomy (2012) juga menyatakan bahwa kalus berstruktur kompak menggambarkan bahwa peluang kalus untuk dikembangkan dan ditumbuhkan lebih lanjut menjadi tanaman utuh (planlet) secara langsung lebih besar.

\section{KESIMPULAN}

Pemberian kombinasi zat pengatur tumbuh NAA dan BAP mempunyai pengaruh terhadap induksi kalus tanaman gaharu. Perlakuan terbaik dalam pembentukan kalus yaitu perlakuan dengan pemberian NAA 3,0 ppm + BAP 0,5 ppm. Tekstur kalus yang didapatkan pada penelitian ini yaitu kompak dengan warna kalus bervariasi yaitu kuning, kuning kecoklatan dan coklat. Kalus yang berwarna kuning dan berstruktur kompak berpeluang dimanfaatkan untuk organogenesis.

\section{DAFTAR PUSTAKA}

Arianto, D., Basri, Z., \& Bustami, M. U. (2013). Induksi kalus dua klon kakao (Theobroma cacao L.) unggul Sulawesi pada berbagai konsentrasi 2, 4 dichlorophenoxy acetic acid secara in vitro. Agrotekbis, 1(3)

Duncan, D. B. (1955). Multiple Range and Multiple F Tests. Biometrics, 11: 1-42.

Fatmawati, A. (2008). Kajian Konsentrasi BAP dan 2,4-D Terhadap Induksi Kalus Tanaman Artemisia annua L. Secara In Vitro [Skripsi]. Fakultas Pertanian, Universitas Sebelas Maret, Surakarta.

Gustian \& Satria, B. (2009). Upaya Perbanyakan Tanaman Penghasil Gaharu (Aquilaria malaccensis Lamk.) Secara In Vitro. Laporan Penelitian Fundamental. Direktorat Jenderal Pendidikan Tinggi. Departemen Pendidikan Nasional. 41 hal.

Hartman, H. T., Kester, D. E., \& Davies Jr, F. T. (1990). Plant Propagation Principles and Practices Fifth Edition. Prentice-Hall, Inc. New Jersey. 
Hayati, K., Surya, N. Y., \& Setiari, N. (2010). Induksi Kalus dari Hipokotil Alfalfa (Mediago sativa L.) Secara In Vitro dengan Penambahan Benzyl Amino Purin (BAP) dan a-Naphtalane Acetic Acid (NAA). Bioma: Berkala Ilmiah Biologi 12 (1): $6-12$.

Isnaini, Y., \& Situmorang, J. (2005). Aplikasi Bioteknologi Untuk Pengembangan Tanaman Gaharu (Aquilaria spp.) di Indonesia. Studi Kasus: Perkembangan Penelitian Gaharu di Seameo Biotrop. Perhimpunan Bioteknologi Indonesia, Malang.

Karlianda, N., Wulandari, R. S., \& Yeni, M. (2012). Pengaruh NAA dan BAP Terhadap Perkembangan Subkultur Gaharu (Aquilaria malaccensis Lamk.) Fakultas Kehutanan, Universitas Tanjungpura, Pontianak.

Lestari, E. G., \& Purnamaningsih, R. (2001). Mikropropagasi Daun Dewa (Gynura pseudochina) Melalui Tunas Adventif. BioSMART 3 (2): $18-22$.

Lizawati. (2012). Proliferasi Kalus Embriogenesis Somatik Jarak Pagar (Jatropha curcas L.) Dengan Berbagai Kombinasi ZPT dan Asam Amino. Bioplantae 1(4): 65-72.

Mahadi, I., Wulandari, S., \& Omar, A. (2014). Pengaruh Naftalen Acetyl Acid (NAA) dan Benzyl Amino Purin (BAP) Terhadap Pertumbuhan Kalus Tanaman Rosella (Hibiscus sabdriffa). Jurnal Biogenesis. 11(1): $1-7$.

Millang, S., Bachtiar, B., \& Makmur, A. (2011). Awal Pertumbuhan Pohon gaharu (Gyrinops sp.) Asal Nusa Tenggara Barat di Hutan Pendidikan Universitas Hasanuddin. Hutan dan Masyarakat, 6(2): 117-124.

Palei, S., Rout, G. R., Das, A. K., \& Dash, D. K. (2017). Callus Induction and Indirect and Indirect Regeneration of Strawberry (Fragria $x$ Ananassa) Duch. International Journal of Current Microbiology and Applied Sciences. 6 (11): 1311 - 1318.

Priyono, D., Suhandi, \& Matsaleh. (2000). Pengaruh Zat Pengatur Tumbuh IAA dan 2-IP pada Kultur Jaringan Bakal Buah Pisang. Jurnal Hortikultura. $10(3): 183-190$.

Ramanta, S. S. (2018). Induksi Kalus Tanaman Gaharu (Aquilaria malaccensis Lamk.) pada Beberapa Konsentrasi 2,4-D secara In-Vitro. [Skripsi]. Fakultas Pertanian, Universitas Andalas, Padang.

Saikia, M., Shrivastava, K., \& Singh, S. S., (2012a). An Efficient Protocol for Callus Induction in
Aquilaria malaccensis Lam. Using Leaf Explants at Varied Concentration of Sucrose. International Journal of Plant Research 2 (6): 188-194.

Saikia, M., Shrivastava, K., \& Singh, S. S., (2013b). Effect of Culture Media and Growth Hormones on Callus Induction in Aquilaria malaccensis Lamk., a Medicinally and Comercially Important Tree Spedies of North East India. Biological Science, 6(2): 96-105.

Satria, B., Dwipa, I., \& Jamsari. (1999). Regenerasi Kalus Manggis (Garcinia mangostana L.) Melalui Kultur In Vitro. Jurnal Stigma Fakultas Pertanian Universitas Andalas, Padang, VII (1), 56-60.

Semiadi, G., Wiriadinata, H., Waluyo, E. B. \& Darnedi, D. (2010). Rantai Pasokan Produk Tumbuhan Gaharu (Aquilaria spp.) asal Merauke, Papua. Buletin Plasma Nutfah, 16(2): 150-160.

Sharma, H., \& Vashistha, B. D. (2015). Plant Tissue Culture: A Biological Tool for Solving The Problem of Propagation of Medicinally Important Woody Plants-A Review. Advanced Research, 3(2): 402-411.

Sumarna, Y. (2003). Budidaya Gaharu. Penebar Swadaya, Bogor.

Thomy, Z. (2012). Effect of Plant Growth Regulator 2,4-D and BAP on Callus Growth of Plants Producing Gaharu. (Aquilaria malaccensis Lamk.). Prosiding Seminar Hasil Nasional Biologi. Medan 11 Mei 2012.

Tsuro, M. (1998). Comparative Effect of Different Types of Cytokinin for Shoot Formation and Plant Regeneration in Leaf-derived Callus of Lavender (Lavandula vera DC). Laboratory of Plant Breeding Science, Faculty of Agriculture, Kyoto Prefectural University.

Wahyuni, D. K., Andriani, P., Ansori, A. N. M., \& Utami, E. S. W. (2017). Callus Induction of Gendarussa (Justicia gendarussa) by Various Concentration of 2,4-D. IBA and BAP. Biosaontifika Journal of Biology \& Biology Education 9(3): 402 - 408.

Yulianti, T. (2015). Induksi Kalus Beberapa Genotipe Jeruk (Citrus sp.) Menggunakan 2,4-D secara InVitro. [Skripsi]. Fakultas Pertanian, Universitas Andalas, Padang.

Zubaidi, A., \& Farida, N. (2008). Pertumbuhan Bibit Gaharu pada Beberapa Jenis Naungan. Crop Agro, 1(2): 92-97.

Zulkarnain. (2009). Kultur Jaringan Tanaman; Solusi Perbanyakan Tanaman Budidaya. Bumi Aksara, Jakarta. 